\title{
Isodeoxyhelicobasidin, a novel human neutrophil elastase inhibitor from the culture broth of Volvariella bombycina
}

\author{
Guang-Hua Xu${ }^{1}$, Young-Hee Kim ${ }^{1}$, Soo-Jin $\mathrm{Choo}^{1}$, In-Ja Ryoo ${ }^{1}$, Chang-Ji Zheng ${ }^{1,2}$, Soon-Ja Seok ${ }^{3}$, \\ Won-Gon Kim ${ }^{1}$ and Ick-Dong Yoo ${ }^{1}$
}

The Journal of Antibiotics (2009) 62, 333-334; doi:10.1038/ja.2009.24; published online 27 March 2009

Keywords: human neutrophil elastase; isodeoxyhelicobasidin; sesquiterpenoid; Volvariella bombycina

Elastin, an important structural protein of extracellular matrix (ECM), is the main component of elastic fiber, which provides resilience and elasticity to many tissues, such as the skin, lungs, ligaments and arterial walls. ${ }^{1,2}$ Human neutrophil elastase (HNE), a serine protease primarily located in the azurophil granules of polymorphonuclear leukocytes, is the only enzyme capable of degrading ECM proteins, such as elastin, collagen, fibronectin, laminin and proteoglycan. ${ }^{3}$ Biologically, elastase activity significantly increases with age and results in a reduced skin elastic property. ${ }^{4}$

In the course of our screening program for HNE inhibitors, we isolated a novel compound, isodeoxyhelicobasidin (1), from the culture broth of Volvariella bombycina (Figure 1). We report herein the fermentation, isolation, structure elucidation and biological activities of 1 .

The strain of $V$. bombycina (MKACC 53745) was provided by the Korea Agricultural Culture Collection of the National Institute of Agricultural Biotechnology, Suwon, Republic of Korea. The producing strain of $V$. bombycina pre-grown on a potato dextrose agar (PDA; Difco, Sparks, MD, USA) slant was inoculated into a 500-ml Erlenmeyer flask containing $100 \mathrm{ml}$ of yeast peptone sucrose (YPS) medium consisting of $2 \%$ glucose, $0.5 \%$ polypeptone, $0.2 \%$ yeast extract, $0.1 \%$ $\mathrm{KH}_{2} \mathrm{PO}_{4}$ and $0.05 \% \mathrm{MgSO}_{4} \cdot 7 \mathrm{H}_{2} \mathrm{O}(\mathrm{pH} 6.6)$, and cultured on a rotary shaker (153 r.p.m.) for 7 days at $27^{\circ} \mathrm{C}$. For fermentation, the seed culture was aseptically transferred into a 5-1 jar fermenter containing 3.51 of the above medium, and cultivation was carried out at $28^{\circ} \mathrm{C}$ for 7 days with aeration of $21 \mathrm{~min}^{-1}$ and agitation of 250 r.p.m., The collected mycelial cake from the whole fermented broth (10 liters) was extracted with acetone and the extract was concentrated in vacuo to an aqueous solution, which was then extracted thrice with equal volume of EtOAc. The EtOAc layer ( $5 \mathrm{~g}$ ) was loaded on a silica gel column and eluted with $\mathrm{CH}_{2} \mathrm{Cl}_{2}-\mathrm{MeOH}$ in a gradient mode $(20: 1 \rightarrow 1: 1)$, the active fraction was subjected to Sephadex LH-20 (GE Healthcare BioSciences AB, Uppsala, Sweden) column chromatography and eluted with $\mathrm{CH}_{2} \mathrm{Cl}_{2}-\mathrm{MeOH}(1: 1)$, and then purified by $\mathrm{YMC} \mathrm{C}_{18}$ preparative HPLC $\left(20 \times 250 \mathrm{~mm}\right.$, flow rate $\left.=4 \mathrm{ml} \mathrm{min}^{-1}, \mathrm{MeOH}-\mathrm{H}_{2} \mathrm{O}=85: 15\right)$ to afford $1\left(6 \mathrm{mg}, t_{\mathrm{R}}=33 \mathrm{~min}\right)$.

Compound 1 was obtained as a yellowish powder; $[\alpha]_{\mathrm{D}}{ }^{20}-25.0$ (c 0.2, MeOH); UV $\left(\mathrm{CHCl}_{3}\right) \lambda_{\max } \mathrm{nm}(\log \varepsilon): 266$ (4.02); IR (KBr) $v_{\max }\left(\mathrm{cm}^{-1}\right): 3434,2964,1650,1633,1368,1304,1210,896 ;{ }^{1} \mathrm{H}$ NMR $\left(\mathrm{CDCl}_{3}, 400 \mathrm{MHz}\right): \delta 7.55(1 \mathrm{H}, \mathrm{s}, 5-\mathrm{OH}), 6.44(1 \mathrm{H}, \mathrm{q}, J=1.6 \mathrm{~Hz}$, $\mathrm{H}-2), 2.93$ (1H, m, H-8a), $2.04(3 \mathrm{H}, \mathrm{d}, J=1.60 \mathrm{~Hz}, \mathrm{H}-15), 1.76-1.74$ (1H, m, H-9a), 1.69-1.67 (1H, m, H-8b), 1.66-1.64 (1H, m, H-10a), 1.63-1.59 (1H, m, H-9b), 1.51-1.44 (1H, m, H-10b), $1.33(3 \mathrm{H}, \mathrm{s}$, $\mathrm{H}-14), 1.12(3 \mathrm{H}, \mathrm{s}, \mathrm{H}-12), 0.84(3 \mathrm{H}, \mathrm{s}, \mathrm{H}-13) ;{ }^{13} \mathrm{C} \mathrm{NMR}\left(\mathrm{CDCl}_{3}, 100\right.$ MHz): ä 188.9 (C-1), 184.8 (C-4), 152.1 (C-5), 139.0 (C-3), 138.4 (C-2), 126.3 (C-6), 51.5 (C-7), 46.3 (C-11), 41.6 (C-10), 39.1 (C-8), 27.8 (C-13), 25.9 (C-12), 24.2 (C-14), 21.3 (C-9), 14.5 (C-15); HRESI-MS $(\mathrm{m} / \mathrm{z}): 247.1342[\mathrm{M}-\mathrm{H}]^{-}$(calcd for $\left.\mathrm{C}_{15} \mathrm{H}_{19} \mathrm{O}_{3}, 247.1340\right)$. The molecular formula of $1, \mathrm{C}_{15} \mathrm{H}_{20} \mathrm{O}_{3}$, was determined by high-resolution mass spectrometry. The UV spectrum of 1 showed an absorption maximum at $266 \mathrm{~nm}$, indicating the presence of 1,4-benzoquinone chromophore. ${ }^{7,8}$ The IR spectrum revealed characteristic absorption bands for hydroxyl group at $3434 \mathrm{~cm}^{-1}$ and conjugated carbonyl group at $1650 \mathrm{~cm}^{-1}$. 9 The ${ }^{1} \mathrm{H}$ NMR spectrum of 1 displayed an enolic hydroxyl proton at $\delta_{\mathrm{H}} 7.55(1 \mathrm{H}, \mathrm{s}, 5-\mathrm{OH})$, a quinonoid proton at $\delta_{\mathrm{H}}$ $6.44(1 \mathrm{H}, \mathrm{q}, J=1.6 \mathrm{~Hz}, \mathrm{H}-2)$ and a quinonoid methyl at $\delta_{\mathrm{H}} 2.04$ $(3 \mathrm{H}, \mathrm{d}, J=1.6 \mathrm{~Hz}, \mathrm{H}-15)$. In addition, it also displayed signals for three tertiary methyl and three methylene groups, which were attributed to cyclopentane ring bearing three tertiary methyl groups. The ${ }^{13} \mathrm{C} N \mathrm{NR}$ spectrum of 1 exhibited 15 carbon resonances consisting of three tertiary methyls, one quinonoid methyl, three methylenes, two quaternary aliphatic carbons, two carbonyl groups, one quinonoid methine

${ }^{1}$ Chemical Biology Research Center, Korea Research Institute of Bioscience and Biotechnology, Yuseong-gu, Daejeon, Korea; ${ }^{2}$ Key Laboratory of Natural Resources and Functional Molecules of Changbai Mountain, Affiliated Ministry of Education, Yanbian University College of Pharmacy, Yanji, Jilin, PR China and ${ }^{3}$ Rural Development Administration (RDA), National Institute of Agricultural Science and Technology, Suwon, Korea

Correspondence: Dr I-D Yoo, Chemical Biology Research Center, Korea Research Institute of Bioscience and Biotechnology, 111 Gwahangno, Yuseong-gu, Daejeon 305-806, Korea.

E-mail: idyoo@kribb.re.kr

Received 10 February 2009; revised 3 March 2009; accepted 4 March 2009; published online 27 March 2009 


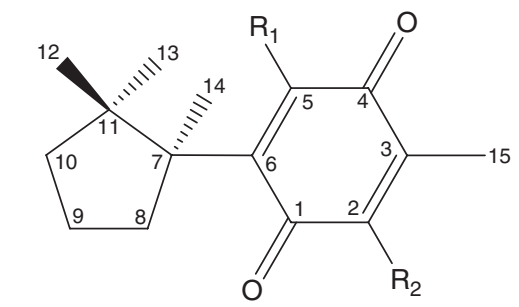

isodeoxyhelicobasidin (1) $\mathrm{R}_{1}=\mathrm{OH}, \mathrm{R}_{2}=\mathrm{H}$

deoxyhelicobasidin $\quad \mathrm{R}_{1}=\mathrm{H}, \quad \mathrm{R}_{2}=\mathrm{OH}$

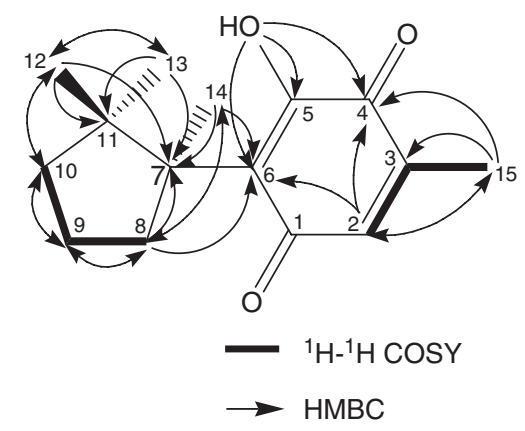

Figure 1 Structure, $1 \mathrm{H}-1 \mathrm{H}$ COSY and HMBC correlations of isodeoxyhelicobasidin (1).

Table 1 HNE inhibitory activity of isodeoxyhelicobasidin (1)

\begin{tabular}{|c|c|c|c|c|c|c|}
\hline \multirow[b]{2}{*}{ Compound } & \multicolumn{5}{|c|}{ Inhibition ratio for HNE (\%) } & \multirow[b]{2}{*}{$1 C_{50^{\mathrm{b}}}(\mu \mathrm{m})$} \\
\hline & $100 \mu \mathrm{m}$ & $30 \mu \mathrm{m}$ & $10 \mu \mathrm{M}$ & $3 \mu M$ & $1 \mu \mathrm{M}$ & \\
\hline 1 & $70.6 \pm 0.7$ & $64.4 \pm 2.0$ & $57.9 \pm 0.8$ & $38.3 \pm 1.4$ & $27.2 \pm 0.3$ & $9.0 \pm 0.9$ \\
\hline EGCG & $65.9 \pm 1.3$ & $62.4 \pm 0.8$ & $47.3 \pm 1.3$ & $25.8 \pm 1.4$ & $17.3 \pm 0.8$ & $12.9 \pm 0.3$ \\
\hline
\end{tabular}

and three quaternary aromatic carbons. All protonated carbons and their protons were assigned by ${ }^{1} \mathrm{H}^{1} \mathrm{H}$ COSY and heteronuclear multiple quantum correlation (HMQC) experiments. The above mentioned spectroscopic data suggested that compound 1 was a cuparene-type sesquiterpenoid, ${ }^{10}$ and the gross structure was further confirmed by COSY and heteronuclear multiple-bond correlation (HMBC) experiments (Figure 1). The COSY correlation of the quinonoid methyl protons at $\delta_{\mathrm{H}} 2.04(\mathrm{H}-15)$ with the quinonoid proton at $\delta_{\mathrm{H}} 6.44(1 \mathrm{H}, \mathrm{q}, J=1.6 \mathrm{~Hz}, \mathrm{H}-2)$ and $\mathrm{HMBC}$ correlations of $\mathrm{H}-15$ with $\mathrm{C}-2$ at $\delta_{\mathrm{C}} 138.4, \mathrm{C}-3$ at $\delta_{\mathrm{C}} 139.0$ and C-4 at $\delta_{\mathrm{C}} 184.8$ suggested that the quinonoid methyl group was at $\mathrm{C}-5$ and the quinonoid methine was at $\mathrm{C}-2$. The hydroxyl proton at $\delta_{\mathrm{H}} 7.55$ (OH-5) was long-range coupled to C-4, C-5 at $\delta_{\mathrm{C}} 152.1$ and C- 6 at $\delta_{\mathrm{C}}$ 126.3 in HMBC spectrum. In addition, HMBC correlations of the tertiary methyl protons at $\delta_{\mathrm{H}} 1.33(\mathrm{H}-14)$ with C-6, C-7 at $\delta_{\mathrm{C}} 51.5$ and $\mathrm{C}-8$ at $\delta_{\mathrm{C}} 39.1$ were observed. These spectral data indicated that 1 was a derivative hydroxylated at C-5 and dehydroxylated at C-2 of deoxyhelicobasidin, which has been isolated from Helicobasidium mompa Tanaka. ${ }^{11}$ The stereochemistry at C-7 of $\mathbf{1}$ was assigned as $S$ configuration by comparison with deoxyhelicobasidin, which also showed a negative optical rotation. Thus, the structure of 1 was established to be $(S)$-5-hydroxy-3-methyl-6-(1,2,2-trimethylcyclopentyl)-1,4-benzoquinone and named as isodeoxyhelicobasidin.

The inhibitory activity of $\mathbf{1}$ on HNE was evaluated with earlier described procedure. ${ }^{12}$ Briefly, each well of a 96-well plate containing $100 \mu \mathrm{l}$ of the following reagents: $10 \mathrm{~mm}$ Tris- $\mathrm{HCl}$ buffer $(\mathrm{pH} 7.5$ ), $1.4 \mathrm{~mm} \mathrm{MeO}$-Suc-Ala-Ala-Pro-Val-p-nitroanilide, $0.18 \mathrm{U} \mathrm{HNE}$ and the sample at various concentrations were incubated for $1 \mathrm{~h}$ at $37^{\circ} \mathrm{C}$ in the dark. After the reaction was stopped by addition of $100 \mu \mathrm{l}$ soybean trypsin inhibitor of $0.2 \mathrm{mg} \mathrm{ml}^{-1}$, absorbance was immediately measured at $405 \mathrm{~nm}$. Epigallocatechin gallate (EGCG) was used as a positive control. As a result, compound $\mathbf{1}$ dose-dependently inhibited HNE activity with an $\mathrm{IC}_{50}$ value of $9.0 \mu \mathrm{m}$, which was comparable to the positive control, EGCG $\left(\mathrm{IC}_{50}, 12.9 \mu \mathrm{m}\right)$ (Table 1). Compound $\mathbf{1}$ also showed antibacterial activity against several gram-positive bacteria including $S$. aureus 503, methicillin-resistant S. aureus CCARM 3167 (MRSA), quinolone-resistant S. aureus CCARM 3505 (QRSA), Bacillus subtilis 1021, Staphylococcus epidermidis 3958 and Streptococcus mutans 3065 with MIC values of $3.1-12.4 \mu \mathrm{g} \mathrm{ml}^{-1} .^{13}$ In conclusion, compound $\mathbf{1}$ was a new analog of helicobasidin and lagopodin B, which were earlier isolated from H. mompa Tanaka and Coprinus cinereus, respectively, ${ }^{14,15}$ and the potent HNE inhibitory activity of $\mathbf{1}$ suggested that it could be useful for the development of anti-aging cosmetics.

\section{ACKNOWLEDGEMENTS}

This work was supported by a grant from the Korea Health 21 R\&D Project, Ministry of Health \& Welfare, Republic of Korea (A050432).

1 Wiedow, O., Schroder, J. M., Gregory, H., Young, J. A. \& Christophers, E. Elafin: an elastase-specific inhibitor of human skin. Purification, characterization, and complete amino acid sequence. J. Biol. Chem. 265, 14791-14795 (1990).

2 Xu, G. H., Ryoo, I. J., Kim, Y. H., Choo, S. J. \& Yoo, I. D. Free radical scavenging and antielastase activities of flavonoids from the fruits of Thuja orientalis. Arch. Pharm. Res. 32, 275-282 (2009)

3 Siedle, B. et al. Sesquiterpene lactones as inhibitors of human neutrophil elastase. Bioorg. Med. Chem. 10, 2855-2861 (2002).

4 Robert, L. Extracellular matrix and aging: a review of mechanisms and interventions. Cosmet. Toiletries 116, 61-70 (2001).

5 Oh, S. U., Yun, B. S., Lee, S. J., Kim, J. H. \& Yoo, I. D. Atroviridins A-C and neoatroviridins $A-D$, novel peptaibol antibiotics produced by Trichoderma atroviride F80317. I. Taxonomy, fermentation, isolation and biological activities. J. Antibiot. 55, 557-564 (2002).

$6 \mathrm{Kim}, \mathrm{J}$. P. et al. Melanocins A, B and C, new melanin synthesis inhibitors produced by Eupenicillium shearii. I. Taxonomy, fermentation, isolation and biological properties. J. Antibiot. 56, 993-999 (2003).

7 Yates, P., Ardao, M. I. \& Fieser, L. F. The infrared spectra of $p$-benzoquinones. J. Am. Chem. Soc. 78, 650-652 (1956).

8 Bycroft, B. W. \& Roberts-John, C. The structure of nidulin. J. Org. Chem. 28, 1429-1430 (1963).

9 Correia-Alves, A., Moreira, M. M., Paul, M. I. \& Cruz-Costa, M. A. A series of eleven dialkyl-hydroxy-p-benzoquinones from Cyperus capitatus. Phytochemistry 31, 2825-2827 (1992).

10 Toyota, M., Koyama, H. \& Asakawa, Y. Sesquiterpenoids from the three Japanese liverworts Lejeunea aquatica, L. flava and L. japonica. Phytochemistry 46, 145-150 (1997).

11 Natori, S., Inoue, Y. \& Nishikawa, H. The structures of mompain and deoxyhelicobasidin and the biosynthesis of helicobasidin, quinonoid metabolites of Helicobasidium mompa Tanaka. Chem. Pharm. Bull. 15, 380-390 (1967).

12 Benedek, B., Kopp, B. \& Melzig, M. F. Achillea millefolium L. s.I. - Is the antiinflammatory activity mediated by protease inhibition? J. Ethnopharmacol. 113, 312-317 (2007).

13 Zheng, C. J., Yu, H. E., Kim, E. H. \& Kim, W. G. Viridicatumtoxin B, a new anti-MRSA agent from Penicillium sp. FR11. J. Antibiot. 61, 633-637 (2008).

14 Natori, S., Nishikawa, H. \& Ogawa, H. Structure of helicobasidin, a novel benzoquinone from Helicobasidium mompa Tanaka. Chem. Pharm. Bull. 12, 236-243 (1964).

15 Bu'Lock, J. \& Darbyshire, J. Lagopodin metabolites and artefacts in cultures of Coprinus. Phytochemistry 15, 2004 (1976). 